\title{
Impacts of land-use and land-cover changes on rockfall propagation: Insights from the Grenoble conurbation
}

\author{
Jérôme Lopez-Saez ${ }^{\mathrm{a}, *}$, Christophe Corona ${ }^{\mathrm{b}}$, Nicolas Eckert ${ }^{\mathrm{c}}$, Markus Stoffel ${ }^{\mathrm{d}, \mathrm{e}, \mathrm{f}}$, \\ Franck Bourrier ${ }^{\mathrm{a}}$, Frédéric Berger ${ }^{\mathrm{a}}$ \\ a Université Grenoble Alpes, Irstea, UR EMGR, 2 rue de la Papeterie, - BP76, F-38402 St-Martin-d'Hères, France \\ b Centre National de la Recherche Scientifique (CNRS), - UMR 6042, - GEOLAB, 63057 Clermont-Ferrand cedex, France \\ c Université Grenoble Alpes, Irstea, UR ETNA, 2 rue de la Papeterie, - BP76, F-38402 St-Martin-d'Hères, France \\ ${ }^{\mathrm{d}}$ University of Geneva, - Institute for Environmental Sciences, Climatic Change and Climate Impacts, 66 Boulevard Carl-Vogt -CH, 1205 Geneva, Switzerland \\ e University of Geneva, - Department of Earth Sciences, 13 rue des Maraîchers, CH, 1205 Geneva, Switzerland \\ ${ }^{\mathrm{f}}$ University of Bern, - Institute of Geological Sciences, - CH-3012 Berne, Switzerland
}

\begin{abstract}
Several studies have debated the incidence of global warming on the probability of rock instability, whereas the impacts of land use and land cover (LULC) changes on rockfall propagation and associated hazards have received comparably little interest. In this study we evaluate the impacts of LULC changes on rockfall hazards on the slopes above the village of Crolles (Chartreuse massif, Grenoble conurbation, French Alps) through a three-level approach: (i) diachronic landscape analysis for four different periods of the past (i.e. 1850, 1956, 1975, and 2013), (ii) computation of 3D rockfall simulations taking explicitly account of reconstructed LULC changes, and (iii) resulting changes in rockfall hazards over time. We reveal that the disappearance of viticultural landscapes (relating to the decline of cropping areas during the interwar period) and intense afforestation of the steepest upper portion of the slope resulted in a significant increase of rockfall return period associated to a gradual decrease of mean kinetic energy at the level of the urban front of Crolles. According to the Eurobloc methodology, the degree of hazard decreased significantly despite the continuous and rapid urban sprawl on the slopes. These results underline that forests can indeed have significant protection function but also call for a more systematic inclusion of LULC changes in hazard assessments in the future.
\end{abstract}

\footnotetext{
* Corresponding author.
} 


\section{Introduction}

Rockfall is commonly defined as the detachment of a rock fragment from a steep rockwall (Selby, 1993) which then travels down the slope to a variable distance by bouncing, falling or rolling (Varnes, 1978). In general, fragmental rockfall involves relatively small detachments of isolated rocks or/and boulders with maximum volumes normally remaining $<30 \mathrm{~m}^{3}$ (Berger and Dorren, 2007). Rockfall is difficult to predict due to its sudden occurrence, lack of reliable precursor signals, poor information on the internal structure of the rock mass, and the multitude of triggering factors such as freeze-thaw cycles of water, melting of snow or permafrost, temperature changes, intense rainfall, stress relief following deglaciation, root penetration, and wedging (Matsuoka and Sakai, 1999; Lambert and Nicot, 2011). Additionally, owing to its high propagation speed and related risks for infrastructure (Harris et al., 2001) and populations, it constitutes one of the most hazardous geomorphic processes in mountainous environments. As for other mass movements, evaluating rockfall hazard includes a determination of occurrence location, actual size of the event, probability of occurrence, runout distance, and energy of time, and all this for a given period of time. The evaluation of rockfall risks then also includes the potential impact on exposed elements such as people, buildings, or transportation corridors (DussaugePeisser et al., 2002).

In the context of rapid environmental changes, several studies have debated the incidence of global warming on the probability of rock instability and the impacts of climate change on the triggering of rockfalls and rock avalanches (Huggel, 2009; Allen and Huggel, 2013; Stoffel et al., 2014). These analyses were mostly based on the retrospective analysis of historical chronicles and supported by the exceptionally warm summer of 2003 when largely increased rockfall activity has been reported throughout the Alps, especially at high elevations and on north-facing slopes (Gruner, 2004; Ravanel and Deline, 2010). Numerous case studies reporting spectacular rock and ice falls in the Alps further support this view (see Stoffel et al., 2014 for a detailed review). Thus, Deline et al. (2012) attributed 55\% of the rockfalls observed in the Mont-Blanc massif in 2007 and 2008 to permafrost degradation, and Allen et al. (2009) found that 13 out of 19 rockfalls investigated in New Zealand originated from marginal permafrost areas. On the other hand, based on rockfall inventory data from Switzerland and Austria, Gruner (2004) and Sass and Oberlechner (2012) stated that a generally increasing frequency of rockfalls at present is neither recognizable nor to be expected in the near future.

Paradoxically, the impacts of land use and land cover (LULC) changes on rockfall propagation and associated hazards has remained only poorly discussed so far. Yet, LULC changes are considered as one of the most rapid drivers of global change (Slaymaker, 2011), especially in mountainous environments of Western Europe where slopes experienced a decrease in total acreage of cultivated areas (MacDonald et al., 2000), an increase in forested areas (Didier, 2001) and, in the industrialized and populated valleys, rapid urban densification (e.g. Falcucci et al., 2007; Bucała, 2014). Hillside instability, with potential consequences on rock fall propagation, tends to be amplified in areas of environmental land use conflicts due to enhanced erosion (Pacheco et al., 2014). In the case of landslides, by contrast, changes in LULC have indeed been identified as having an effect as predisposing factors on landslide occurrence (Glade, 2003; Beguería, 2006), but that they may also control the spatial distribution of consequences. Furthermore, land cover type has been recognized to significantly affect rockfall runout distance as a result of changes in restitution coefficients (Dorren, 2012a, 2012b; Perret et al., 2004) and thus areas at risk.

In this study, the impacts of LULC changes on rockfall propagation were investigated with a retrospective analysis. In a first step, LULC changes have been quantified for the slopes of the Chartreuse Massif (French Alps) for four different periods since 1850. This area has undergone (i) an intense agro-pastoral decline since the mid-19th century and (ii) a rapid periurbanisation - related to the vicinity of the Grenoble conurbation (500,000 inhabitants) - since the 1950s. Using the documented changes in LULC as input parameters, we then simulated rockfall trajectories for four different dates $(1850,1956,1975,2013)$ with the probabilistic process-based rockfall trajectory model RockyFor3D. This analysis then allowed determination of return periods and mean kinetic energy of rockfalls and therefore also definition of associated risk at the urban front of Crolles for each of the time steps and different block sizes (from 1.2 to $17 \mathrm{~m}^{3}$ ).

\section{Study site}

The village of Crolles $\left(45^{\circ} 17^{\prime} 09^{\prime \prime} \mathrm{N}, 5^{\circ} 53^{\prime} 01^{\prime \prime} \mathrm{E}\right)$ is located in the Grenoble conurbation on the southeastern slopes of the Chartreuse Massif (French Alps; Fig. 1A). The municipality extends from the "Bec Margain» (1036 m a.s.l.) to the Isère River (220 m a.s.l.) and covers an area of $14.2 \mathrm{~km}^{2}$, three of which are located on the slopes of the Chartreuse massif (Fig. 1B). Since the 1950s, LULC on these concave talus slopes (250-600 $\mathrm{m}$ a.s.l.) have changed substantially in a way which can be considered typical for south-facing slopes in the French Prealps.

Covered with vineyard (Fig. 1C) since the mid-19th century, these slopes have experienced a rapid agropastoral decline during the interwar period, followed by intense periurban expansion since the mid-20th century. At Le Fragnès, Magny, Ardillais, and Le Coteau, neighborhoods started to spread upslope (Fig. 1D), thereby inducing a sharp increase $(+864 \%$ ) of local population ( 964 inhabitants or 67 persons $\mathrm{km}^{-2}$, in 1946 against 8344 inhabitants or 588 persons $\mathrm{km}^{-2}$ in 2011).

The village of Crolles has constantly faced rockfall hazards as reflected in toponymy, since the root of Crolles, corrotulare, literally means to roll a block in Latin language. Rockfalls are released from a 300 m-high sub-vertical cliff made of thick-bedded limestones and marls from the upper Jurassic period (Dussauge-Peisser et al., 2002). Strata dip gently inward and three sub-vertical discontinuity sets can be observed at the site, one parallel to the direction of the cliff surface, and two others crossing it. The most common rockfall mechanisms are wedge failures, initiated on these two crossing sets, tower toppling and overhang failures, where the succession of limestone and marls suffers from differential erosion (Dussauge-Peisser et al., 2002). Archival records report number of rockfall events since 1900 with rockfall fragments varying from clasts with edge lengths of only a few decimeters to blocks with volumes $>30 \mathrm{~m}^{3}$. Fresh blocks, recent impact craters on the ground and visible growth disturbances (i.e. scars, decapitated trees) on the forest stand confirm ongoing intense rockfall activity during the last decades. As a consequence, three protective walls (with lengths of 400,500 , and $800 \mathrm{~m}$, respectively) have been constructed since 1995 to reduce rockfall risk in the neighborhoods of Magny, Ardillais and Le Coteau, the latter one being reached by two blocks $\left(>20 \mathrm{~m}^{3}\right)$ on 15 January 2012 . Additionally a $1-\mathrm{km}$ long protection wall is already planned for the next decade to protect Le Fragnès neighborhood. 
A

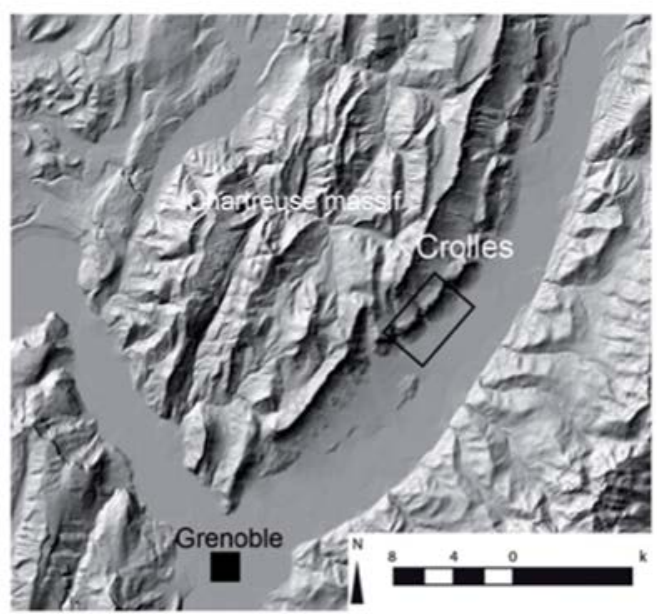

B

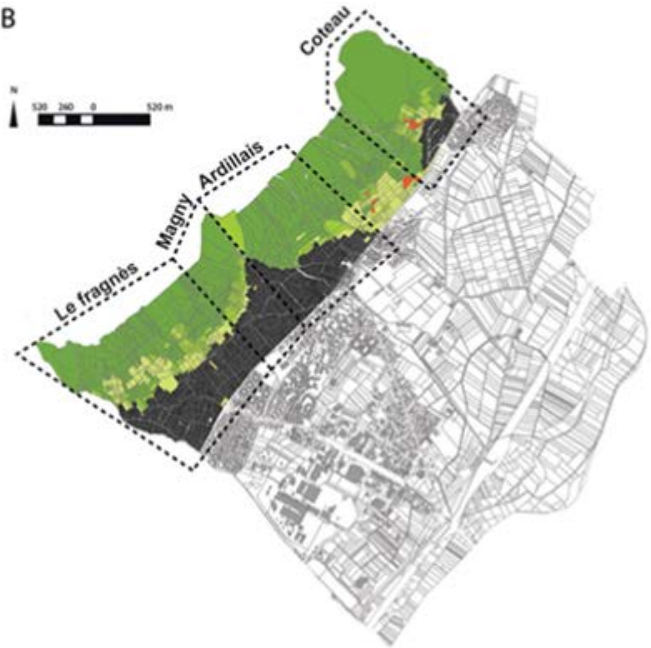

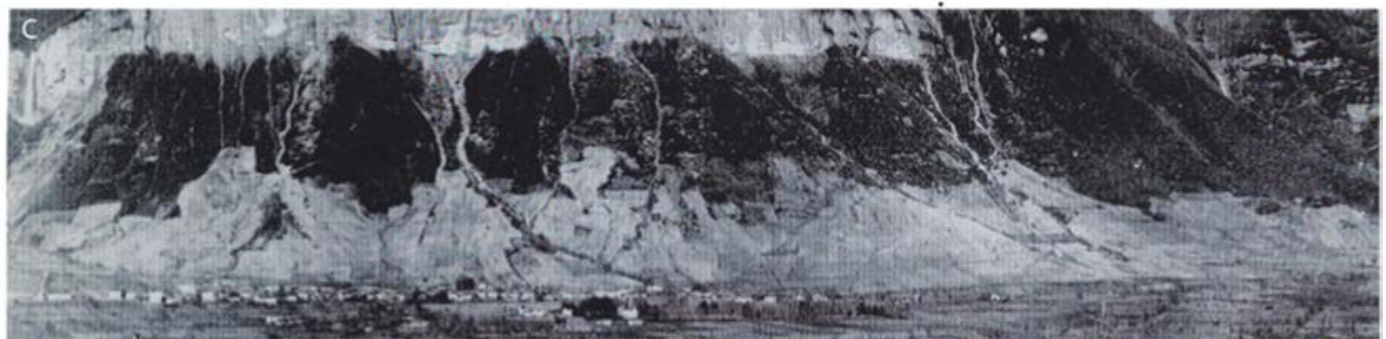

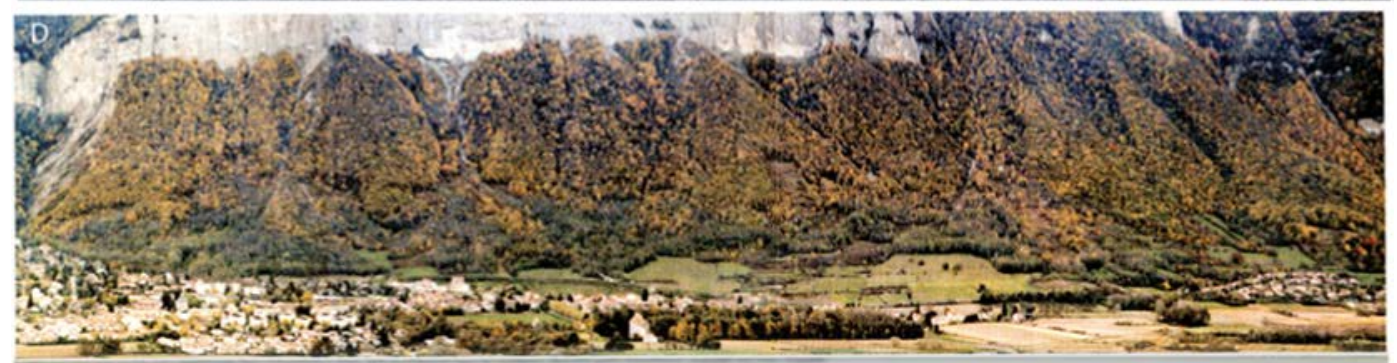

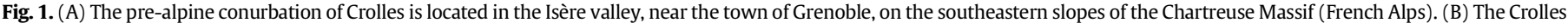

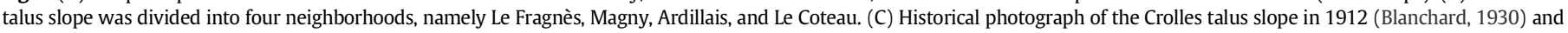
current photograph of the village in 2013 (D).

\section{Material and methods}

The impacts of LULC changes on rockfall hazard were evaluated through a three-step approach. In a first step, (i) a time-dependant analysis of cartographic records was used to evaluate changes in LULC patterns for four dates between 1850 and 2013. In a second step, (ii) rockfall trajectories were simulated, for the same dates, and for four different block sizes (1.2 to $17 \mathrm{~m}^{3}$ ) using the 3D rockfall model RockyFor3D. For each set of simulations, (iii) the return period and the mean kinetic energy of blocks was assessed at the level of the urban front so as to quantify the impacts of landscape changes and reorganization on rockfall hazards.

\subsection{Analysis of LULC changes}

Spatio-temporal dynamics of land use and land cover (LULC) changes are typically analyzed with time series of cartographic documents (cadastral, topographic maps, aerial photographs; Houghton et al., 2012). In France, such documents reach back to the 19th century, such that the Napoleonic cadastral map could be used for the establishment of a baseline for LULC. This map has been ostensibly created for taxation purposes (Eynard-Machet, 1993) and therefore offers a precise and detailed record of land ownership and use at the level of allotments (Coughlan, 2013). At Crolles, the Napoleonic cadastral map has been used to detail the state of LULC for the reference period 1850 . Since 1956, three aerial flight campaigns were available from the French National Geographic Institute (IGN) with a sufficient resolution to detect LULC changes at the scale of allotments, namely in 1956, 1975, and 2013 (always in a scale of $1: 30,000)$. Aerial photo interpretation realized using standard photographic keys (i.e., tone, texture, pattern, shape, and size) and supplemented with secondary information on geomorphology, historical vegetation maps, and ground truth data. For 2013, additional information available from the French digital cadastre database and field observations were used to assess LULC. Based on these physiographic constraints, visual interpretation and digitalization (Kennedy, 2013) was conducted, at the scale of allotments, to generate thematic maps of LULC patterns, at each of the four dates. Six classes of LULC types were distinguished, namely (i) forest, (ii) culture, (iii) untilled land, (iv) grassland, (v) vineyard, and (vi) municipality. Through this sequential analysis, the net change in cover $\left(\mathrm{km}^{2}\right)$ as well as gains and losses $\left(\mathrm{km}^{2}\right)$ of the six land cover types between 1850 and 2013 were quantified using IDRISI land change modeler (Warner and Campagna, 2009). 


\subsection{Modeling rockfall trajectories in different LULC patterns}

On the basis of a Digital Elevation Model, rockfalls at Crolles were simulated using RockyFor3D (v5.0) (Dorren, 2012a, 2012b), a probabilistic process-based rockfall trajectory model that combines-physically based, deterministic algorithms with stochastic approaches to simulate rockfall in three dimensions. The model calculates sequences of classical, uniformly accelerated parabolic free fall through the air and rebounds on the slope surface and on trees (for details see Dorren et al., 2005). During each rebound, the model allows the block to deviate from its direction before rebound toward the direction of the aspect of the terrain in which the block rebounds. If an impact against a tree takes place, part of the rock energy is dissipated as a function of the stem diameter of the corresponding tree and of the relative position between rock and tree center. After a tree impact, the trajectory of a rock can be deviated laterally up to $76^{\circ}$ from its fall direction before the tree impact.

LULC patchiness is explicitly integrated in RockyFor3D through its spatial modeling possibilities. Parameters used to characterize the interactions between the block and the soil - the soil mechanical properties (i.e. restitution coefficients) and the soil roughness - are implicitly related with LULC. In addition, the model provides information about rock propagation for any location in the study site such as the number of passing rocks through a given surface or percentiles of the distribution of the kinetic energy of rocks entering a cell, for example.

\subsection{Mapping of potential release areas (PRa)}

Required model input data mainly includes a set of raster maps describing the (i) Digital Elevation Model (DEM) used to determine the mean slope gradient, fall direction and impact locations of falling rocks on the slope surface based on kinematic equations (e.g. Guzzetti et al., 2002), (ii) rockfall source cells including rock density, dimensions, and shape, (iii) density of trees per cell, (iv) distribution of trees in each cell, (v) wood type per cell (i.e. broadleaved or coniferous), (vi) mechanical properties of the surface material per cell, and (vii) roughness of the slope surface per cell. At Crolles, a high-resolution DEM $(2.5 \times 2.5 \mathrm{~m})$ was produced through the interpolation (Ordinary Kriging) of LiDAR (Light Detection And Ranging laser scanning) point data with an average of six points per raster cell.

The morphology of a terrain displays characteristic slope angles that can be directly related to the geomorphic processes involved in slope stability; rockfall source areas are commonly found in the steepest morphological units (Michoud et al., 2012). Based on these statements, Loye et al. (2009) have established a DEM-based geomorphometric approach to detect these morphological units and therefore rockfall source areas, also know as Slope Angle Frequency Distribution (SAFD) procedure. In this procedure, slope angle distribution is decomposed in several Gaussian distributions which can be considered characteristic of morphological units (such as rock cliffs, steep slopes, foot slopes, and plains). The terrain is considered a potential rockfall source if its slope angle exceeds a certain threshold, which in turn is defined where the Gaussian distribution of the morphological unit «rock cliff» becomes dominant over the "steep slope» unit. According to this analysis, based on the Histofit routine (Loye et al., 2009), the threshold slope angle for source areas was fixed to $49^{\circ}$. Thereafter, potential rockfall source areas were mapped, integrated into a Geographical Information System (GIS) and converted to raster. The total surface of the potential release areas (Pra) was evaluated to correspond to $31.5 \mathrm{hm}^{2}$. The rock density in each source start cell was set at $2700 \mathrm{~kg} \cdot \mathrm{m}^{-3}$.

\subsection{Block design and associated recurrence intervals (Ri)}

This paper aims at quantifying the impact of LULC on rockfall propagation. From this perspective, the choice of the design block volume is crucial. Potential rockfall volumes were constrained from a power law distribution function established through the 3-year LiDAR monitoring of the Saint-Eynard calcareous cliff $(750 \times 200 \mathrm{~m}$ in width and height, Jurassic age), located $10 \mathrm{~km}$ southwest of the study site (Guerin et al., 2014). From this power law distribution, recurrence intervals ( $R i$, in year) for rock volumes (V) ranging from 0.05 to $100 \mathrm{~m}^{3}$ triggered from the $31.5 \mathrm{hm}^{2}$ potential release area of Crolles are of the form:

$$
\mathrm{Ri}=\left(1 / 0.85 * \mathrm{~V}^{-0.75}\right) / \text { Pra }
$$

According to this distribution and based on recent rockfalls observed in the field, rock volumes of 1.2 (V1), 5 (V2), 10 (V3) and $17 \mathrm{~m}^{3}$ (V4) were designed for rockfall simulations corresponding to recurrence intervals of $0.043,0.12,0.21,0.31$ year, respectively. To obtain sufficiently stable outputs, 100 rockfalls were triggered from each of the $2.5 \mathrm{~m}^{2}$ source cell yielding a total of 5,042,200 rockfalls per simulation campaign. This number of repetitions was considered an acceptable tradeoff between computation time and stability of results and was therefore used for all the simulation campaigns (Trappmann et al., 2014). For all simulations we used a rectangular block form, additional initial fall height of $2 \mathrm{~m}$ and we included the forest as an obstacle for falling rocks.

\subsection{Input data on transit area}

In the transit area, Rockyfor3D uses a normal and a tangential coefficient of restitution to calculate rock rebound on the slope surface (Volkwein et al., 2011). The normal coefficient of restitution ( $\mathrm{rn}$ ) defines the change in normal velocity during impact. In Rockyfor3D, rn values are associated with slope materials depending on mechanical properties, i.e. the capacity of slope materials to dissipate energy, in particular. The tangential coefficient of restitution ( $\mathrm{rt}$ ) defines the reduction in tangential velocity during impact. Both coefficients are depending on (i) the rock shape and radius and by (ii) the depth of the impact crater during a rebound (Dorren et al., 2005).

As the composition and size of the material covering the slope surface and normal restitution coefficients are closely linked to land use, they were translated into six LULC classes (Table 1). Roughness was not associated to cultivated land (i.e. grassland, vineyard, untilled land, culture allotments) and urbanized areas in 1850. Instead, obstacles which could have been hit a falling blocks have been removed. The forest allotments present in 1850 were mainly located on steep scree slopes. These forests have always had a protective function, and have thus been given greater surface roughness ( $\operatorname{Rg} 10$ : $0.3 \mathrm{~m}$; Rg20: $0.2 \mathrm{~m}$; Rg70: $0.05 \mathrm{~m}$ ) as compared to their denser coverage of rock debris.

\subsection{Impacts of LULC changes on rockfall propagation}

In total, seven scenarios were evaluated, and for each scenario four block volumes were considered (V1-V4, see subchapter 3.4 for details). Noteworthy the reference scenario (RefSC) does not include a forest stand. SC1-SC3 are based on LULC in 1850 but account for different tree densities in 1850. SC4-SC6 are based on LULC in 1956, 1975, 2013, respectively (see details below).

In RefSC, we aim at isolating the influence of topography on rockfall propagation. As a consequence, no tree cover has been included in the model. By contrast, in scenarios SC1-SC6, several forest parameters susceptible to influence the dissipation of kinetic energy of rock masses in the case of collisions with trees have been considered, such as tree diameter, tree density, species composition and spatial arrangement of trees in forest. These parameters were included in simulations with the forest module of Rockyfor3D. According to field observations and given the low productivity of the forest stand at Crolles, mean diameter of trees at breast height (DBH) was set to $20 \mathrm{~cm}( \pm 10 \mathrm{~cm})$. Based on these stand parameters, the model then randomly placed a given number of $20 \pm 10 \mathrm{~cm}$ DBH trees within each of the forested allotments. 
Table 1

RockyFor3D model input parameters used for scenarios SC1-SC6 in the transit area.

\begin{tabular}{|c|c|c|c|c|c|c|c|c|c|c|}
\hline \multirow[b]{2}{*}{ LULC type } & \multicolumn{4}{|l|}{ Nr. trees $\cdot$ ha } & \multirow[t]{2}{*}{ DBH mean } & \multirow[t]{2}{*}{ DBH stand } & \multirow[t]{2}{*}{ rn } & \multirow[t]{2}{*}{ RG10 } & \multirow[t]{2}{*}{ RG20 } & \multirow[t]{2}{*}{ RG70 } \\
\hline & 1850 (SC1-SC3) & 1956 (SC4) & 1975 (SC5) & 2013 (SC6) & & & & & & \\
\hline \multirow[t]{2}{*}{ Forest } & $1500-1000-750$ & 1500 & 1500 & 1500 & 20 & 10 & 0.38 & $0.3(1850)$ & $0.2(1850)$ & $0.05(1850)$ \\
\hline & & & & & & & 0.28 & 0 (other date) & 0 (other date) & 0 (other date) \\
\hline Untilled land & 200 & 400 & 400 & 400 & 10 & 5 & 0.28 & 0 & 0 & 0 \\
\hline Grassland & & & & & & & 0.28 & 0 & 0 & 0 \\
\hline Culture & & & & & & & 0.28 & 0 & 0 & 0 \\
\hline Vineyard & & & & & & & 0.28 & 0 & 0 & 0 \\
\hline Urban & & & & & & & 0.28 & 0 & 0 & 0 \\
\hline
\end{tabular}

Similarly, for untilled land, the mean tree DBH was set to $10 \mathrm{~cm}$ $( \pm 5 \mathrm{~cm})$

In 2013 (SC6), the densities of forest (1500 stems $\cdot \mathrm{ha}^{-1}$ ) and untilled land ( 400 stems $\cdot \mathrm{ha}^{-1}$ ) allotments were determined within four plots $(50 \times 50 \mathrm{~m})$ distributed along a transect in the upper part of the slope. Similar parameters were adopted for the forest in SC4 (1956) and SC5 (1975). As this contribution aims at evidencing the influence of land abandonment and afforestation on rockfall propagation, the protective walls realized at the study site were not included in the numerical simulations of the current situation (2013; SC6).

In 1850, old photographs (Fig. 1C) reveal the presence of a sparse forest stands at Crolles. In the absence of historical forest inventories and to account for more intense logging before the mid-20th century, three decreasing forest $\left(1500,1000\right.$ and 750 stems $\left.\cdot \mathrm{ha}^{-1}\right)$ and untilled land $\left(200\right.$ stems $\left.\cdot \mathrm{ha}^{-1}\right)$ densities were successively implemented in Rockyfor3D (SC1-SC3).

\subsection{Rockfall return period $(R p)$ and mean kinetic energy (MKE)}

An assessment of rockfall hazard requires both data on return period and on intensity (i.e., kinetic Energy) as key input data (Raetzo et al., 2002). At Crolles the return periods (Rp) of rockfalls at the level of the urban front have been computed as follows:

$R p=R i(V) / R p r o b$

Rprob $=$ Nbsim $/ \Sigma$ simulations

where, $R i(V)$ is the recurrence interval for rockfall volumes V1 to V4 (according to Guerin et al., 2014). Rprob was computed as the ratio between the number of rockfall deposits below the urban front and the total number of simulations. Finally, the mean kinetic energy (MKE) per cell was extracted from the raster layers issued by Rockyfor3D for
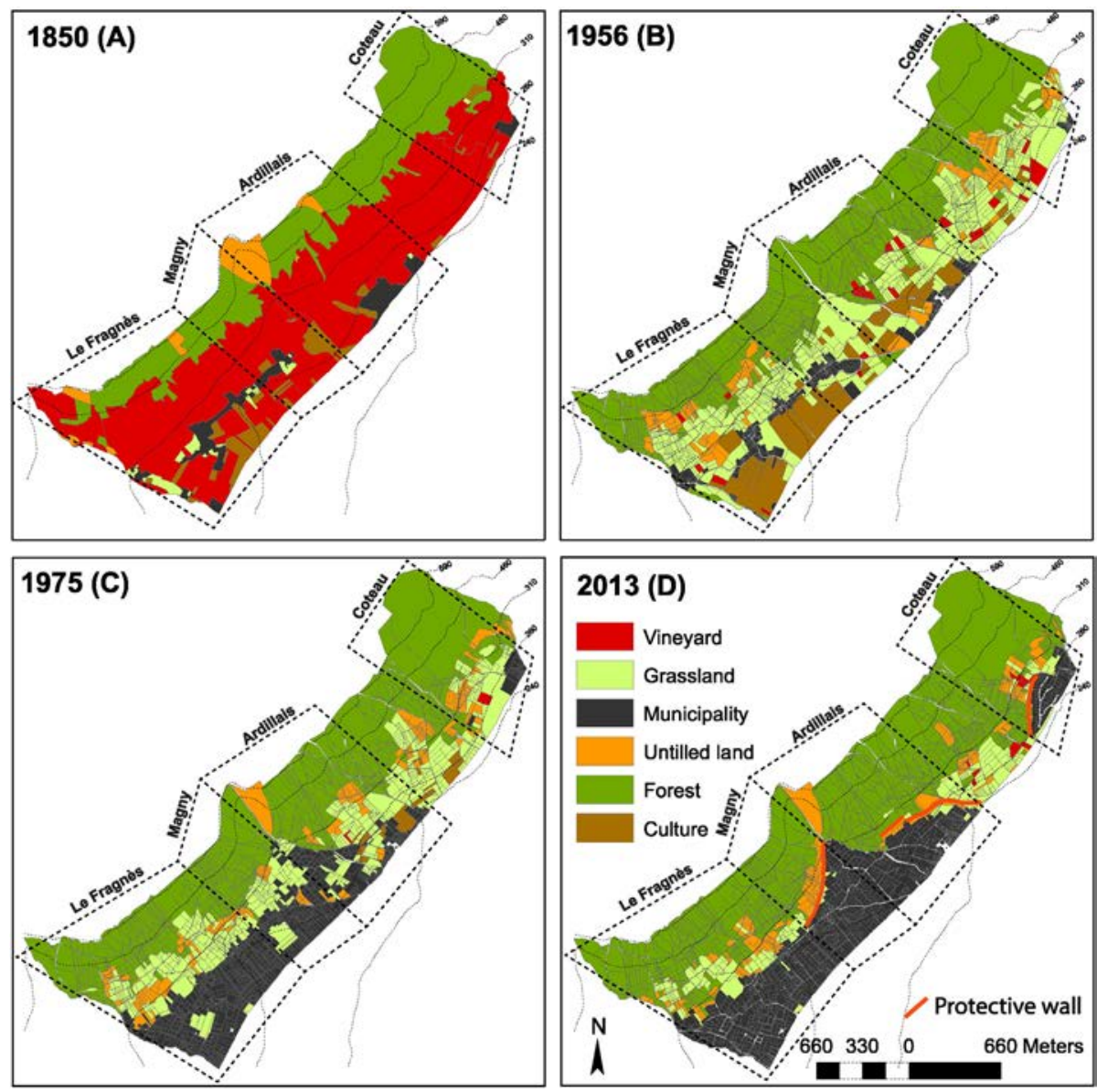

Fig. 2. Land use and land cover (LULC) maps of the Crolles slope in (A) 1850, (B) 1956, (C) 1975, and (D) 2013. 


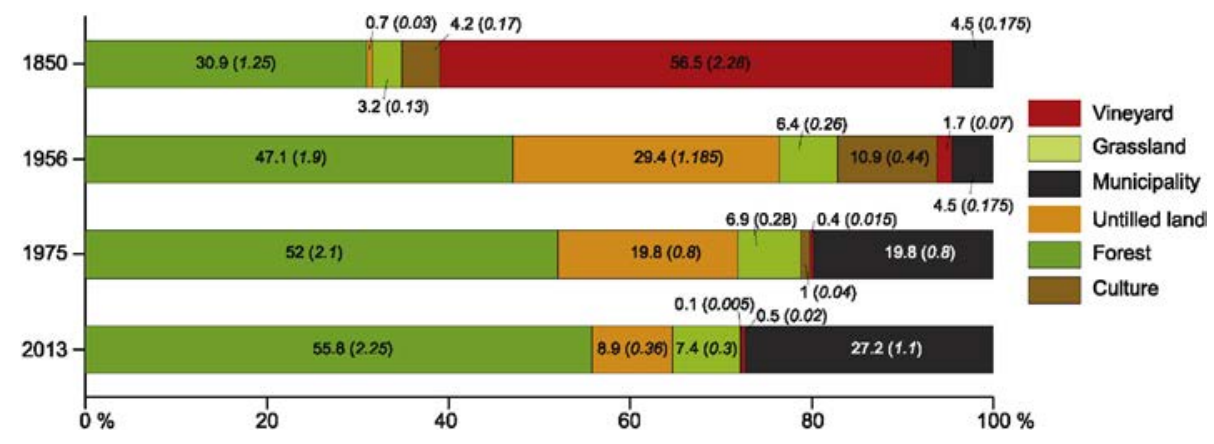

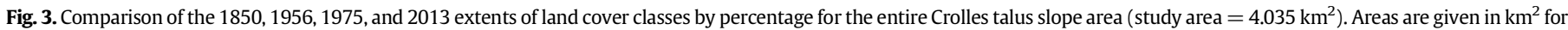
each LULC class.

each cell intercepted by the urban front, each date and each block volume.

\section{Results and discussion}

\subsection{Land use and land cover changes since 1850}

At Crolles, land use and land cover (LULC) underwent major changes since 1850. The maps shown in Fig. 2 indicate a clear trend toward an increase in forest cover and urban areas between 1850 and 2013 (Fig. 3). In 1850 (Fig. 2A), the slope is characterized by a quasi-binary landscape with (i) vineyards (56.5\% of the total surface) occupying slope gradients of up to $28^{\circ}$ and at altitudes below $450 \mathrm{~m}$ a.s.l. where a (ii) continuous forest strip (30.9\%, mean length: $300 \mathrm{~m}$ ) then takes over to extend up to the base of the calcareous cliff. Urban and cultivated allotments are scattered below $280 \mathrm{~m}$ a.s.l. but only cover spatially limited surfaces, typically on gentle slopes $\left(<13^{\circ}\right)$ around Le Fragnès and Magny neighborhoods. Noteworthy, landscapes - comparable to the case described here - have been widespread until the mid-19th century on most of the south-exposed slopes of the Alpine furrow which extends on more than $140 \mathrm{~km}$ from Geneva (Blache, 1923; Blanchard, 1930; Vaudaine, 1930). According to Blanchard (1930), high grape yields ( $>5000 \mathrm{hl}$ per year at Crolles) would have resulted from both the favorable soils and exposition of the southern slopes of the Chartreuse Massif. The existence of a local market for wine products in the garrison towns of Grenoble and Chambéry has further favored intense exploitation of relatively steep slopes $\left(\leq 28^{\circ}\right)$. Conversely, Blache (1923) and Jail (1967) also state that local forest stands were mostly restricted to the upper part of slopes where excessive slope angles, rocky soils and frequent rockfall prevented sustainable agricultural exploitation.

Between 1850 and 1956 (Fig. 2B), maps evidence a generalized abandonment the vineyards (down to $1.7 \%$ of the total surface) with a net loss of $2.21 \mathrm{~km}^{2}$ of cultivated lands (Fig. 3). Schematically speaking, downslope wine plots have been replaced by grasslands $(+2140 \%$ in 1956). The upslope allotments (on slopes $>20^{\circ}$ ) have been abandoned first and were either replaced by untilled land or colonized by the upcoming forest $(47.1 \%$ of the total surface, mean length of the forest strip: $455 \mathrm{~m}$ ). The urban front, which is potentially exposed to rockfalls, has, at the same time, increased by $280 \mathrm{~m}$ and thus reveals only a limited lateral urban sprawl (Fig. 2A, B). Several reasons are responsible for the progressive abandonment of viticulture and associated LULC changes on the slopes at Crolles, in addition to the first and second world wars: (i) the phylloxera (Phylloxera vastatrix) outbreak - a parasite of the genus Vitis - has reached Crolles in 1880 and destroyed most of the vineyard in less than 10 years (Veyret-Verner, 1937; Stevenson, 1980); (ii) several attempts to replace local vines affected by phylloxeraby e.g., resistant American cep vines (Noah and Clinton ceps) have been unsuccessful and resulted in poorer quality of wines; (iii) the increasing concurrence of wines from southeastern France and (iv) the disappearance of the Grenoble military market in 1925 (Grandvoinnet, 2011).

Between 1956 and 1975 (Fig. 2C), the abandonment of agricultural plots $\left(-0.4 \mathrm{~km}^{2}\right)$ and the spread of the forest (net change in cover: $+0.2 \mathrm{~km}^{2}$, mean length: $523 \mathrm{~m}$ ) continue to affect the areas upslope of the main constructed areas. This same period is also characterized by a rapid urban sprawl as revealed by a clear increase of the potentially exposed urban front $(+808 \mathrm{~m})$ and more than a fourfold increase of constructed areas, especially in the Le Fragnès and Magny neighborhoods.

Finally, in 2013 (Fig. 2D), the non-forested surfaces represent less than $9 \%$ of the total surface and constitute a narrow and discontinuous transitional strip between constructed (27.2\% of the total surface) and wooded (forest + untilled land $=64 \%$ of the total surface; length of the protection forest strip $=601 \mathrm{~m}$ ) plots. The length of the urban front potentially exposed to rockfall also increased by $635 \mathrm{~m}$ since 1975. During these decades, landscape evolution was mainly controlled by the rapid expansion of the peri-alpine conurbation of Grenoble. More specifically, land pressure on the slopes of Crolles has been attributed to the scarcity of land in the Isère Valley and, in addition, to the favorable exposition of slopes at Crolles (Briquel, 2001; Perlik et al., 2001).

\subsection{Sensitivity analyses in 1850 (SC1-SC3)}

Accounting for the lack of information on forest structure in 1850 , three sets of simulations (SC1-SC3) were successively tested in Rockyfor3D; they correspond to three different forest densities $\left(\mathrm{SC} 1=1500, \mathrm{SC} 2=1000\right.$ and SC3 $=750$ stems $\cdot$ ha $\left.^{-1}\right)$ (Table 1$)$. Fig. 4 presents the spatial distribution of rockfall deposits for SC3 and for block volumes of 1.2 (V1) and $5 \mathrm{~m}^{3}$ (V2). Return period (in years) are computed at the level underneath the 300 -m wide forest strip (Table 2). In the case of $\mathrm{V} 1, R p$ values are generally low with 0.27 (SC3), 0.29 (SC2) and 0.3 (SC1) years, respectively. These values are 7 times higher than the recurrence interval $(\mathrm{Ri}(\mathrm{V} 1)=0.043$ years $)$ computed for V1. Therefore, results obtained confirm the protective effect of the forest and are in line with recommendations given for protection forest management for which (i) a minimum forest strip of $200 \mathrm{~m}$ (Gauquelin, 2006) (ii) a density of 300-400 trees/ha with DBH $(>24 \mathrm{~cm}$ ), and (iii) small inter-tree distances (gaps) are defined as ideal to protect goods and people against rockfalls of limited volume (Gsteiger, 1993; Frehner et al., 2005). When larger volumes are used $\left(\mathrm{V} 4=17 \mathrm{~m}^{3}\right), R p$ values range between 0.45 and 0.49 and only slightly differ from Ri (0.31). By contrast to V1, model results suggest that the forest can only provide a limited protection in the case of large block volumes (V4) and irrespective of stand density, as it was also proposed by e.g., Stokes (2006).

Conversely, for intermediate block volumes (i.e. V2 $=5 \mathrm{~m}^{3}$ and $\mathrm{V} 3=10 \mathrm{~m}^{3}$ ), the proportion of blocks passing the forest strip is 

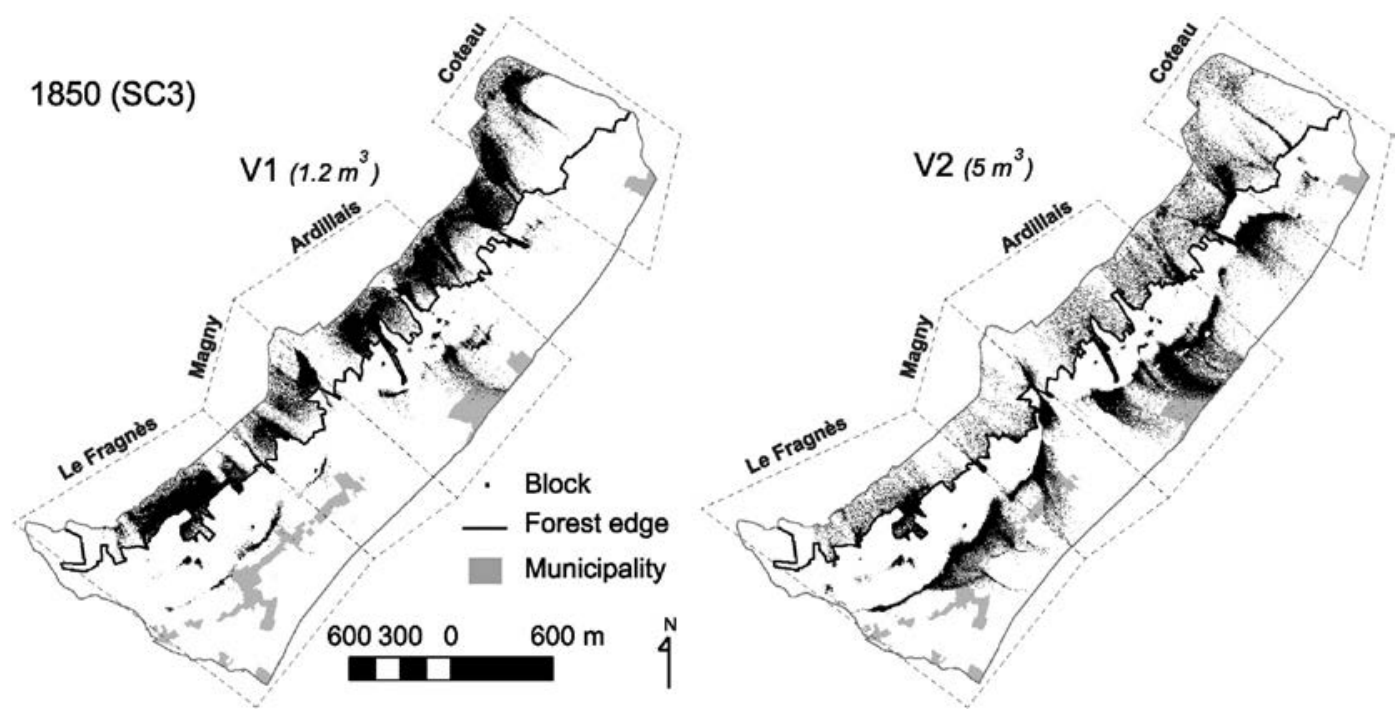

Fig. 4. Spatial distribution of rockfall deposits as simulated in RockyFor3D for 1850 (SC3), for block volumes of 1.2 (V1) and $5 \mathrm{~m}^{3}$ (V2).

significantly influenced by stem density. In the case of V2, $R p$ varies between 0.65 (SC1) and 0.34 (SC3, - 91\%) for stem densities ranging from 1500 to 750 stem.ha ${ }^{-1}$, respectively. In the case of $\mathrm{V} 3$, it decreases from 0.51 (SC1) to 0.36 (SC3, - 41\%). In the literature, protection forests are usually considered as effective barriers providing significant mitigating effects against rockfalls for volumes of up to $5 \mathrm{~m}^{3}$ (Dorren et al., 2005; Stokes, 2006). Our results, however, suggest that an increase in forest density would permit to enhance the protective function even in case that rock volumes go up to $10 \mathrm{~m}^{3}$.

Based on these results and so as to evaluate the number of blocks that could potentially reach the forest and the urban fronts at different moments back in time, we only retain the "worst" scenario (SC3) for which 750 stems $\cdot \mathrm{ha}^{-1}$ are included in the 1850 time step.

\subsection{Evolution of the Rp at the level of the urban front between 1850 and 2013}

At the slope scale, and regardless of the block volume, we observe a sharp increase of Rp values since 1850 (Table 3B). When using volumes according V1, a $R p$ of 143 years is calculated for 1850 . By contrast, not a single block of the same size actually reached the urban front in 2013 (SC6). For volumes V2, V3, and V4, the $R p$ increased from 14,10 , and 5 to 5000, 167 and 16 years between 1850 and 2013 (Table 3B), thus confirming the increasingly higher degree of protection provided by a widening forest strip.

A close examination of the evolution of rockfall passages along a representative 1000-m-long elevational transect located in the Le Fragnès neighborhood (Fig. 5) allows for a more detailed assessment of these evolutions. In 1850 (Fig. 5A), the sharp decrease of rockfall passages in the apical portion of the talus (i.e. within the uppermost $200 \mathrm{~m}$ ) reveals the protective effect of the forest stand for volumes up to $5 \mathrm{~m}^{3}$. Conversely, for volumes $\geq 10 \mathrm{~m}^{3}$, we observe strong similarities between

Table 2

Return period (in years) of rockfalls in 1850 computed at the level underneath the $300-\mathrm{m}$ wide forest strip for each scenario $\left(\mathrm{SC} 1=1500, \mathrm{SC} 2=1000\right.$ and SC3 $=750$ stems $\cdot \mathrm{ha}^{-1}$ ) and each block volume (V1-V4).

\begin{tabular}{lllll}
\hline & $\mathrm{V} 1\left(1.2 \mathrm{~m}^{3}\right)$ & $\mathrm{V} 1\left(1.2 \mathrm{~m}^{3}\right)$ & $\mathrm{V} 1\left(1.2 \mathrm{~m}^{3}\right)$ & $\mathrm{V} 4\left(17 \mathrm{~m}^{3}\right)$ \\
\hline Rp (years) & & & & \\
SC1 (1850) & 0.3 & 0.65 & 0.51 & 0.49 \\
SC2 (1850) & 0.29 & 0.44 & 0.4 & 0.46 \\
SC3 (1850) & 0.27 & 0.34 & 0.36 & 0.45 \\
\hline
\end{tabular}

the reference scenario (RefSC) - computed without trees - and SC3, a clear indication for the rather limited role of trees on rockfall propagation. For these large volumes, a sharp decrease in rockfall passages is observed between 270 and $330 \mathrm{~m}$ a.s.l. where (i) slope angles drop to $24^{\circ}$ and material enters the depositional zone (Francou and Manté, 1990; Luckman, 2013) and where (ii) maximum concavity can be observed within the talus slope. Results obtained for V3 and V4 also suggest that for the situation in 1850 , rockfall propagation at the site was predominantly controlled by topography and especially by slope curvature.

One hundred years later, in 1956 (Fig 5B), rockfall frequency decreased in two ways: (i) in the uppermost $250 \mathrm{~m}$ of the slope profile, the steep decline of rockfall frequency is mainly related to the densification of the forest stand (from 750 to $1500 \mathrm{stem} \cdot \mathrm{ha}^{-1}$ ); whereas (ii) below $270 \mathrm{~m}$ a.s.l., the decreasing number of passages coincides with a marked concavity (from $19^{\circ}$ to $13^{\circ}$ ) in the slope profile. In addition, differences between the RefSc and SC4 for block volumes V3 and V4, also suggest a reduced influence of slope segmentation on rockfall propagation in the central portion of the talus slope (270-550 $\mathrm{m}$ a.s.l.). For large blocks $\left(\geq 10 \mathrm{~m}^{3}\right)$, rockfall frequencies remain rather stable between 1956 and 1975 (Fig. 5C), despite significant enlargement of the forest strip. More interestingly, between 1975 and 2013 (Fig. 5D), and despite a rather limited afforestation of the most concave portions of the slope, results reveal a sharp increase of $R p$ for block volumes V2, V3, and V4. As a consequence, we hypothesize that this portion of the talus profile - located between 270 and $300 \mathrm{~m}$ a.s.l. - plays a key role in terms of rockfall protection, especially for larger block volumes.

\subsection{Evolution of the kinetic energy between 1850 and 2013}

The probability density functions of the mean kinetic energy (MKE) were extracted from the raster layers issued by Rockyfor3D at each cell intercepted by the urban Front (Fig. 6). As expected, mean MKE decrease with rock volumes (Table 3B, Fig. 6) in addition to varying over time. In 1850, the highest MKE values observed at the level of the urban front are attributed to (i) the high slope values in the steepest portions of the vineyard which tend to accelerate rock movement and to (ii) weak soil roughness of cultivated allotments which will not decelerate rockfalls; results thus also confirm that blocks will override slope roughness and propagate further provided that the size of falling rocks is greater than average roughness asperities (Lambert and Nicot, 2011). By contrast, lower kinetic energies are systematically observed since 1956, thus illustrating the protective effects of untilled land allotments in efficiently dissipating energy, even if they are scattered 


\section{Table 3}

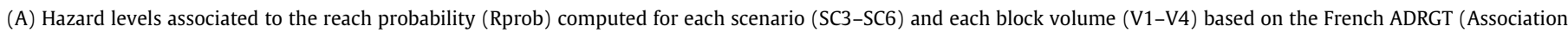

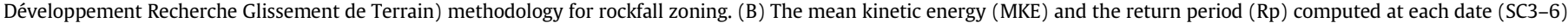
and for each block volume (V1-4) and associated hazard levels based on the Eurobloc intensity-frequency matrix.

A

\begin{tabular}{|c|c|c|c|c|}
\hline & $\mathrm{V} 1\left(1.2 \mathrm{~m}^{3}\right)$ & $\mathrm{V} 2\left(5 \mathrm{~m}^{3}\right)$ & V3 $\left(10 \mathrm{~m}^{3}\right)$ & $\mathrm{V} 4\left(17 \mathrm{~m}^{3}\right)$ \\
\hline \multicolumn{5}{|l|}{ Rprob } \\
\hline SC3 (1850) & 0.0002 & 0.0098 & 0.024 & 0.068 \\
\hline SC4 (1956) & 0 & 0.0013 & 0.017 & 0.068 \\
\hline SC5 (1975) & 0.000017 & 0.004 & 0.024 & 0.068 \\
\hline SC6 (2013) & 0 & 0.000027 & 0.0014 & 0.021 \\
\hline
\end{tabular}

\begin{tabular}{|llll} 
& \multicolumn{1}{c}{$10^{-2}$} & $10^{-4}$ & $10^{-6}$ \\
\hline High & & Moderate & Low \\
& & & \\
\hline
\end{tabular}

B

\begin{tabular}{|c|c|c|c|c|}
\hline & $\mathrm{V} 1\left(1.2 \mathrm{~m}^{3}\right)$ & $\mathrm{V} 2\left(5 \mathrm{~m}^{3}\right)$ & V3 $\left(10 m^{3}\right)$ & $\mathrm{V} 4\left(17 \mathrm{~m}^{3}\right)$ \\
\hline \multicolumn{5}{|c|}{ Rp (years) / (MKE (Kj)) } \\
\hline SC3 (1850) & 143 (1109) & 14 (4293) & $10(6702)$ & $5(16362)$ \\
\hline SC4 (1956) & $\infty$ & $100(525)$ & $14(1160)$ & $5(3590)$ \\
\hline SC5 (1975) & 2000 (49) & 33 (357) & $10(1248)$ & $5(3880)$ \\
\hline SC6 (2013) & $\infty$ & $5000(634)$ & 167 (1250) & 16 (3014) \\
\hline
\end{tabular}

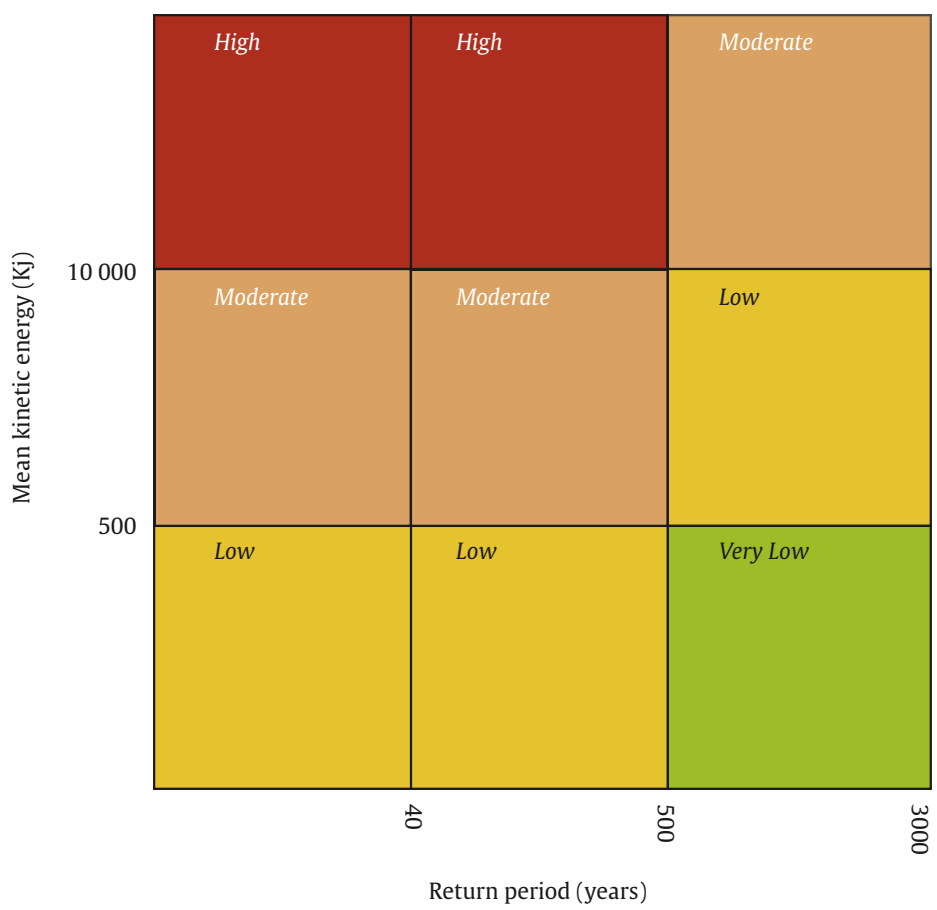



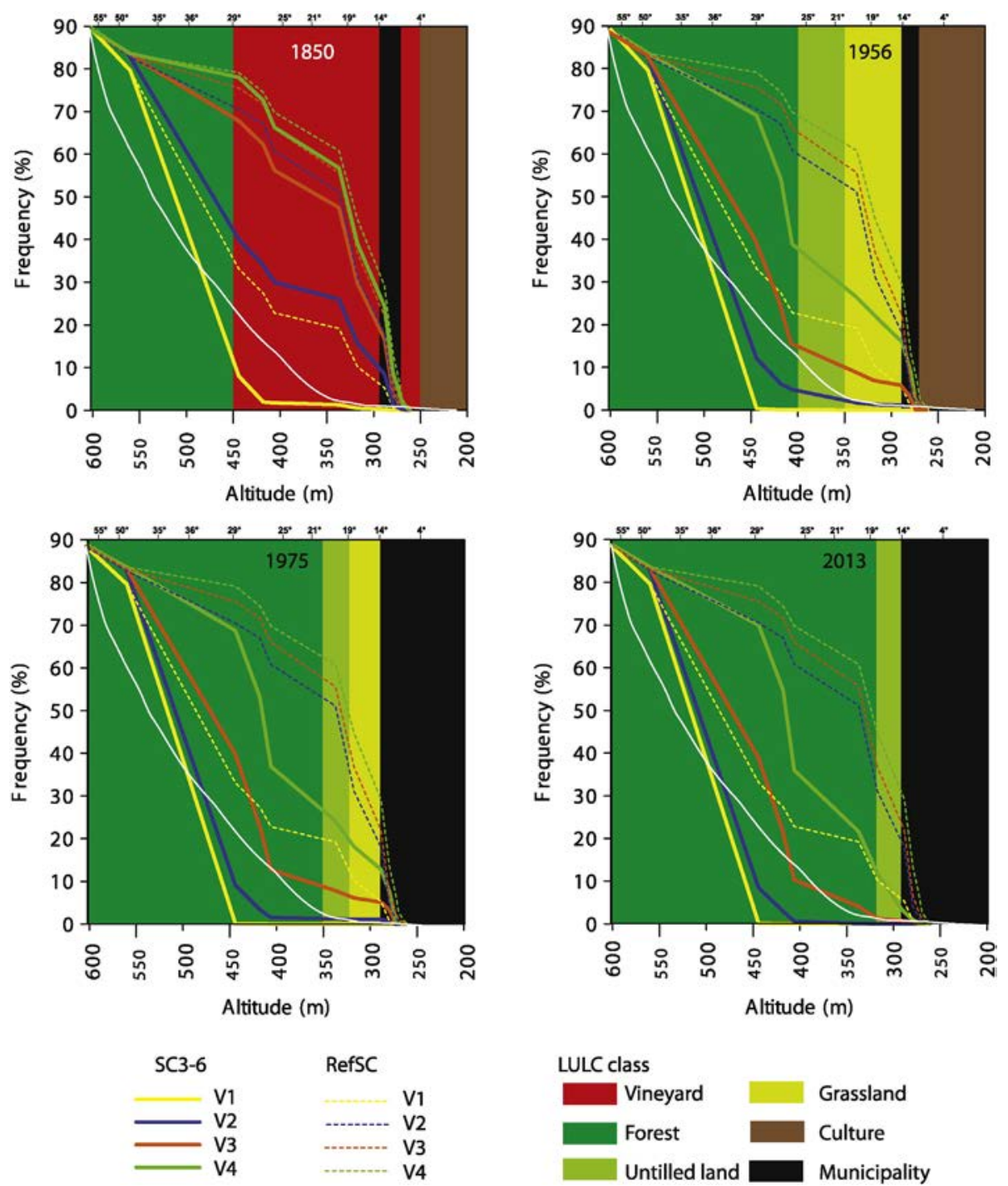

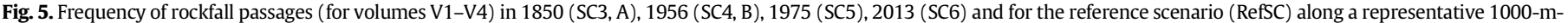
long elevational transect (in white) located in the Le Fragnès neighborhood.

throughout the slope, as was the case in 1956. Here, the decrease of MKE between the forest and the urban front is mainly attributed to the collision of blocks with trees, a mechanism which has been demonstrated to significantly reduce the velocity of rockfalls (Dorren and Berger, 2006).

\subsection{Impacts of LULC changes on rockfall hazards since 1850}

In this contribution we quantified the evolution of rockfall hazards at Crolles since the mid-19th century based on ADRGT and Eurobloc methodologies: (i) the French ADRGT (Association Développement Recherche Glissement de Terrain) and (ii) the Eurobloc methodology.

The French methodology used for rockfall zoning, called ADRGT (Association Développement Recherche Glissement de Terrain; Desvarreux, 2002, 2007) suggests reach probability (Rprob) of $10^{-2}$, $10^{-4}, 10^{-6}$, and 0 to be translated into zones which highly, moderately, slightly or not exposed to rockfalls. Based on Rprob values (Table 3A), high, moderate, low or null hazards were assigned to the urban front of Crolles (Abbruzzese and Labiouse, 2010). According to the ADRGT methodology, despite the extension of the urban front, the hazard levels associated with 1.2 (V1) and $5 \mathrm{~m}^{3}$ (V2) blocks decreased from moderate in 1850 to null (low) in 2013 while they remain moderate throughout the period for $10(\mathrm{~V} 3)$ and $17 \mathrm{~m}^{3}(\mathrm{~V} 4)$ blocks. (ii) The Eurobloc methodology combines the frequency of rockfall events and energy (Mavrouli et al., 2014) to discriminate five degrees of rockfall hazards (going from null to high). According to the Eurobloc methodology, the degree of hazard decreased from moderate to null for small volumes (V1, V2) since 1956 and in 2013, respectively. For V3, and despite a sharp decline of MKE since ca. 1956 which was associated with a clear increase of Rp since 1975 (from 10 to 167 years), the hazard level remains moderate over the entire period. For very large block volumes (V4), the decline of the hazard level from high to moderate between 1850 and 1956 mainly results from the reduction of MKE, with the latter being related to higher tree density in the upper part of the slope (Perret et al., 2004), and a widening of the forest strip between 350 and $400 \mathrm{~m}$ a.s.l. Importantly and whatever zoning methodology is being used, our results thus reveal quite clearly that LULC changes contributed to (i) significantly reduce rockfall hazards for volumes up to $5 \mathrm{~m}^{3}$, and to (ii) maintain rockfall hazard at the same regulatory level for volumes $>10 \mathrm{~m}^{3}$, despite the fact that the urban front which is potentially exposed to rockfall has seen an increase by $100 \%$ since 1850 . Yet, we also have to underline that the results of this study should not be used for zoning purposes. Indeed, one of the shortcomings of this study is the quantification of the level of hazards at Crolles, as the mapping of hazard levels has not been realized for each district individually. In addition, future work should focus in more detail on the identification of rockfall 

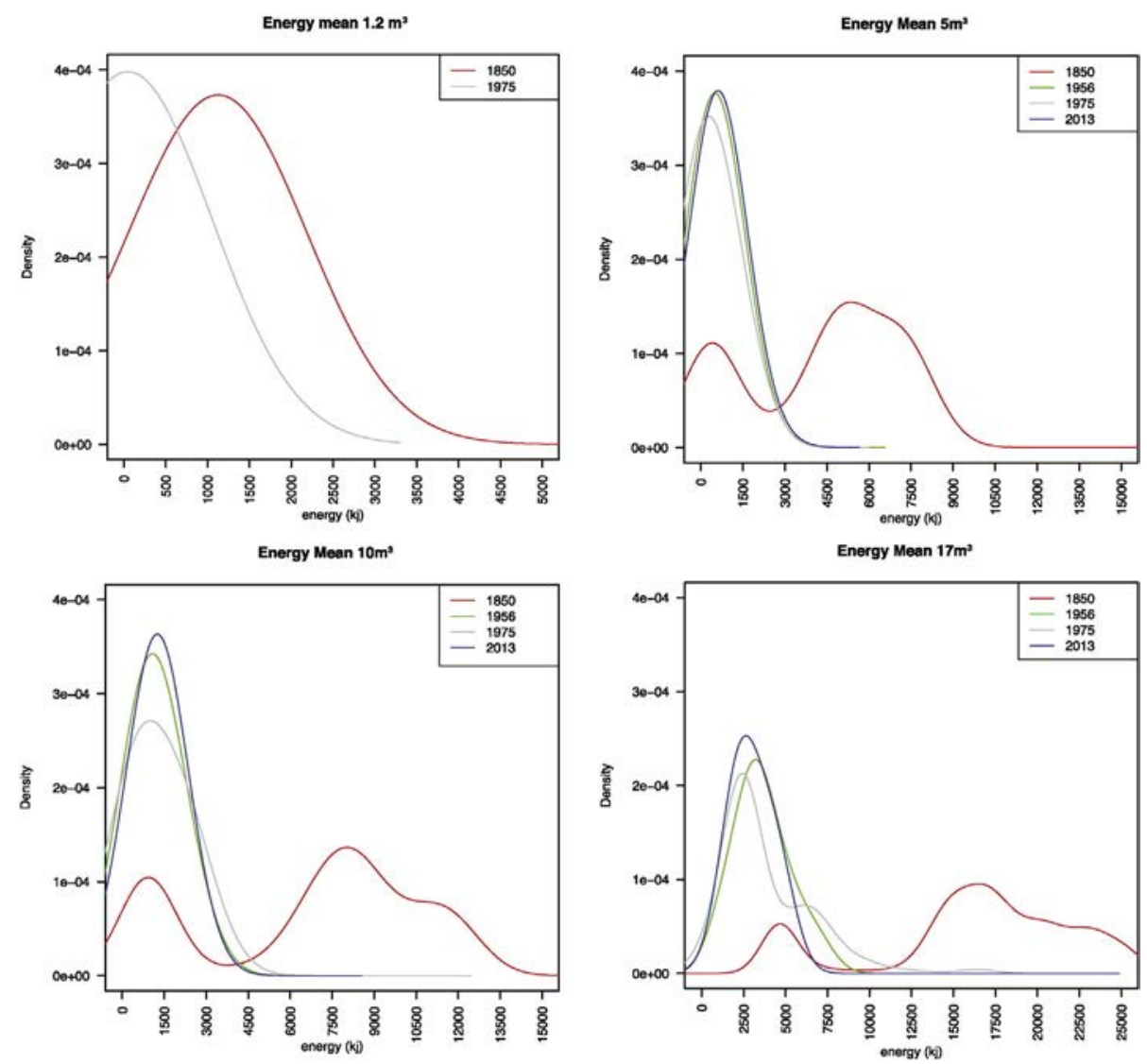

Fig. 6. Probability density functions of the mean kinetic energy for each scenario (SC3-SC6) and each block volume (V1-V4) at each cell intercepted by the Crolles urban front.

source cells, model each district separately and compute Rprob and MKE specifically for each of the neighborhoods considered in this study. At the same time, similar studies seem not realistic at a lower spatial scales (allotments) at present to (i) the impossibility to associate one or more source cells to each of the allotments, (ii) uncertainties related to the differential productivity of each source cell, (iii) technical limitations related to the storage of each rockfall trajectory which would prevent the extraction of reach probabilities at the pixel scale, (iv) the impossibility to precisely attribute specific soil mechanical properties to each of the allotments.

\section{Conclusions}

This study is among the first to detail effects of land use and land cover changes on rockfall propagation and associated level of hazards. Through the coupled analysis of diachronic landscape evolution and rockfall simulations on the talus slopes above Crolles, we document the rapid afforestation after land abandonment as well as intense periurbanisation since the mid-19th century. We consequently demonstrate that landscape reorganization induced an increase of (i) return period at Crolles and a gradual decrease of (ii) mean kinetic energy of blocks since 1850 . For blocks up to $5 \mathrm{~m}^{3}$, the decrease of rockfall frequency and energy since 1956 is mainly attributed to the densification of the forest stand in the upper part of the slope. Our study further demonstrates the key role of the protection forest in controlling rockfalls and their reach which has favored significant reduction of hazard levels at the urban front of Crolles despite rapid urbanization of the talus slope since 1850. During the last decades a lot of attention has been paid to the influence of climatic changes on rockfall activity whereas the impacts of land use and land cover changes have almost systematically been disregarded. Our findings demonstrate the added value of a dynamic approach accounting for land use and land cover changes for future hazard assessment but also call for more research on this barely addressed topic.

\section{Acknowledgments}

This research has been supported by the national research project C2ROP (Chutes de blocs, Risques Rocheux, Ouvrages de Protection) supported by the MEDDE, French Ministry of Ecology, Sustainable Development and Energy. It has also been supported by ANR SAMCO (Adaptation de la société aux risques en montagne dans un contexte de changement global).

\section{References}

Abbruzzese, J.M., Labiouse, V., 2010. Challenges in achieving European-wide methodologies for rock fall hazard mapping. Mountain Risks Conference - Bringing science to society, Firenze, Italy, 24-26 November.

Allen, S., Huggel, C., 2013. Extremely warm temperatures as a potential cause of recent high mountain rockfall. Glob. Planet. Chang. 107, 59-69. http://dx.doi.org/10.1016/j. gloplacha.2013.04.007.

Allen, S.K., Gruber, S., Owens, I.F., 2009. Exploring steep bedrock permafrost and its relationship with recent slope failures in the Southern Alps of New Zealand. Permafr. Periglac. Process. 20, 345-356. http://dx.doi.org/10.1002/ppp.658.

Beguería, S., 2006. Changes in land cover and shallow landslide activity: a case study in the Spanish Pyrenees. Geomorphology 74, 196-206.

Berger, F., Dorren, L.K.A., 2007. Principles of the tool Rockfor.net for quantifying the rockfall hazard below a protection forest. Schweiz. Z. Forstwes. 158, 157-165. http://dx doi.org/10.3188/szf.2007.0157.

Blache, J., 1923. Carte viticole des abords des Alpes dauphinoises du Nord. Rev. Géogr. Alp. $11,449-456$.

Blanchard, R., 1930. La répartition de la vigne dans les Alpes françaises. Rev. Géogr. Alp. $18,219-260$.

Briquel, V., 2001. L'avancée de la périurbanisation dans les Alpes du Nord françaises et ses liens avec la croissance récente de la population. Rev. Géogr. Alp. 89, 21-40. http://dx. doi.org/10.3406/rga.2001.3020.

Bucała, A., 2014. The impact of human activities on land use and land cover changes and environmental processes in the Gorce Mountains (Western Polish Carpathians) in 
the past 50 years. J. Environ. Manag. 138, 4-14. http://dx.doi.org/10.1016/j.jenvman. 2014.01.036.

Coughlan, M.R., 2013. Errakina: pastoral fire use and landscape memory in the Basque Region of the French Western Pyrenees. J. Ethnobiol. 33, 86-104. http://dx.doi.org/10. 2993/0278-0771-33.1.86.

Didier, L., 2001. Invasion patterns of European larch and Swiss stone pine in subalpine pastures in the French Alps. For. Ecol. Manag. 145, 67-77. http://dx.doi.org/10. 1016/S0378-1127(00)00575-2.

Dorren, L.K.A., 2012a. Rockyfor3D (v 5.0) Revealed - Transparent Description of the Complete 3D Rockfall Model, EcorisQ Paper. Association EcorisQ St. Hilaire Touvet.

Dorren, L.K.A., 2012b. A review of rockfall mechanics and modelling approaches. Prog. Phys. Geogr. 27, 69-87. http://dx.doi.org/10.1191/0309133303pp359ra.

Dorren, L.K.A., Berger, F., 2006. Stem breakage of trees and energy dissipation during rockfall impacts. Tree Physiol. 26, 63-71. http://dx.doi.org/10.1093/treephys/26.1.63.

Dorren, L.K.A., Berger, F., Le Hir, C., Mermin, E., Tardif, P., 2005. Mechanisms, effects and management implications of rockfall in forests. For. Ecol. Manag. 215 (1-3), 183-195.

Dussauge-Peisser, C., Helmstetter, A., Grasso, J.-R., Hantz, D., Desvarreux, P., Jeannin, M. Giraud, A., 2002. Probabilistic approach to rock fall hazard assessment: potential of historical data analysis. Nat. Hazards Earth Syst. Sci. 2, 15-26. http://dx.doi.org/10. 5194/nhess-2-15-2002.

Eynard-Machet, R., 1993. Anciens cadastres et évolution des paysages. Cartographie historique de l'occupation des sols dans les Alpes de Savoie, France. Rev. Géogr. Alp. 81, 51-66. http://dx.doi.org/10.3406/rga.1993.3719.

Falcucci, A., Maiorano, L., Boitani, L., 2007. Changes in land-use/land-cover patterns in Italy and their implications for biodiversity conservation. Landsc. Ecol. 22, 617-631. http://dx.doi.org/10.1007/s10980-006-9056-4.

Francou, B., Manté, C., 1990. Analysis of the segmentation in the profile of alpine talus slopes. Permafr. Periglac. Process. 1, 53-60. http://dx.doi.org/10.1002/ppp.3430010107.

Frehner, M., Wasser, B., Schwitter, R., 2005. Nachhaltigkeit und Erfolgskontrolle im Schutzwald - Wegleitung für Pflegemassnahmen in Waldern mit Schutzfunktion (Technical Report). Swiss Federal Office for the Environment FOEN, Bern.

Gauquelin, X., 2006. Guide des Sylvicultures de Montagne: Alpes du Nord Françaises. Cemagref de Grenoble, Saint-Martin-d'Hères.

Glade, T., 2003. Landslide occurrence as a response to land use change: a review of evidence from New Zealand. Catena 51, 297-314.

Grandvoinnet, P., 2011. Les emprises militaires dans l'urbanisme grenoblois du XX siècle: des opportunités foncières au patrimoine paysager. In Situ 16. http://dx.doi. org/10.4000/insitu.217.

Gruner, U., 2004. Klima und Sturzereignisse in Vergangenheit und Zukunft. http://dx.doi. org $/ 10.5169 /$ seals-224994.

Gsteiger, P., 1993. Steinschlagschutzwald - Ein Beitrag zur Abgrenzung, Beurteilung und Bewirtschaftung. Schweiz. Z. Forstwes. 144, 115-132

Guerin, A., Hantz, D., Rossetti, J.-P., Jaboyedoff, M., 2014. Brief communication "Estimating rockfall frequency in a mountain limestone cliff using terrestrial laser scanner. Natual Hazards and Earth System Sciences Discussion. 2, pp. 123-135. http://dx.doi.org/10. 5194/nhessd-2-123-2014.

Guzzetti, F., Crosta, G.B., Detti, R., Agliardi, F., 2002. STONE: a computer program for the three-dimensional simulatation of rock-falls. Comput. Geosci. 28 (9), 1081-1095.

Harris, C., Davies, M.C.R., Etzelmüller, B., 2001. The assessment of potential geotechnica hazards associated with mountain permafrost in a warming global climate. Permafr. Periglac. Process. 12, 145-156. http://dx.doi.org/10.1002/ppp.376.

Houghton, R.A., House, J.I., Pongratz, J., van der Werf, G.R., DeFries, R.S., Hansen, M.C., Le Quéré, C., Ramankutty, N., 2012. Carbon emissions from land use and land-cover change. Biogeosciences 9, 5125-5142. http://dx.doi.org/10.5194/bg-9-5125-2012.

Huggel, C., 2009. Recent extreme slope failures in glacial environments: effects of thermal perturbation. Quat. Sci. Rev. 28, 1119-1130. http://dx.doi.org/10.1016/j.quascirev. 2008.06.007.

Jail, M., 1967. Grands travaux publics dans le Grésivaudan et quelques conséquences sur la vie agricole. Rev. Géogr. Alp. 55, 702-706. http://dx.doi.org/10.3406/rga.1967.3345.

Kennedy, M., 2013. Introducing Geographic Information Systems with ArcGIS: A Workbook Approach to Learning GIS. third ed. John Wiley \& Sons, Hoboken, New Jersey.

Lambert, S., Nicot, F., 2011. Rockfall Engineering. ISTE; Wiley, London: Hoboken, NJ.

Loye, A., Jaboyedoff, M., Pedrazzini, A., 2009. Identification of potential rockfall source areas at a regional scale using a DEM-based geomorphometric analysis. Nat. Hazards Earth Syst. Sci. 9, 1643-1653. http://dx.doi.org/10.5194/nhess-9-1643-2009.
Luckman, B.H., 2013. Talus Slopes. The Encyclopedia of Quaternary Science. Elsevier, Amsterdam, pp. 566-573.

MacDonald, D., Crabtree, J., Wiesinger, G., Dax, T., Stamou, N., Fleury, P., Gutierrez, L.J., Gibon, A. 2000. Agricultural abandonment in mountain areas of Europe: environmental consequences and policy response. J. Environ. Manag. 59, 47-69. http://dx. doi.org/10.1006/jema.1999.0335.

Matsuoka, N., Sakai, H., 1999. Rockfall activity from an alpine cliff during thawing periods. Geomorphology 28, 309-328. http://dx.doi.org/10.1016/S0169-555X(98)00116-0.

Mavrouli, O.C., Abbruzzese, J., Corominas, J., Labiouse, V., 2014. Review and advances in methodologies for rockfall hazard and risk assessment. In: Van Asch, T., Corominas, J. Greiving S., Malet, J.-P., Sterlacchini, S. (Eds.), Mountain Risks: From Prediction to Management and Governance. Springer, Netherlands, Dordrecht, pp. 179-199.

Michoud, C., Derron, M.H., Horton, P., Jaboyedoff, M., Baillifard, F.J., Loye, A., Nicolet, P., Pedrazzini, A., Queyrel, A., 2012. Rockfall hazard and risk assessments along roads at a regional scale: example in Swiss Alps. Nat. Hazards Earth Syst. Sci. 12, 615-629. http://dx.doi.org/10.5194/nhess-12-615-2012.

Pacheco, F.A.L., Varandas, S.G.P., Sanches Fernandes, L.F., Valle Junior, R.F., 2014. Soil losses in rural watersheds with environmental land use conflicts. Sci. Total Environ. 485486C, 110-120.

Perlik, M., Messerli, P., Bätzing, W., 2001. Towns in the Alps: urbanization processes, economic structure, and demarcation of European Functional Urban Areas (EFUAs) in the Alps. Mt. Res. Dev. 21, 243-252. http://dx.doi.org/10.1659/0276-4741(2001)021[0243: TITA]2.0.CO;2.

Perret, S., Dolf, F., Kienholz, H., 2004. Rockfalls into forests: analysis and simulation of rockfall trajectories ? considerations with respect to mountainous forests in Switzerland. Landslides 1, 123-130. http://dx.doi.org/10.1007/s10346-004-0014-4.

Raetzo, H., Lateltin, O., Bollinger, D., 2002. Hazard assessment in Switzerland - codes of practice for mass movements. Bull. Eng. Geol. Environ. 61, 263-268. http://dx.doi. org/10.1007/s10064-002-0163-4.

Ravanel, L., Deline, P., 2010. Climate influence on rockfalls in high-Alpine steep rockwalls: the North Side of the Aiguilles de Chamonix (Mont Blanc massif) since the end of the 'Little Ice Age'. The Holocene 21, 357-365. http://dx.doi. org $/ 10.1177 / 0959683610374887$

Sass, O., Oberlechner, M., 2012. Is climate change causing increased rockfall frequency in Austria? Nat. Hazards Earth Syst. Sci. 12, 3209-3216. http://dx.doi.org/10.5194/ nhess-12-3209-2012.

Selby, M.J., 1993. Hillslope Materials and Processes. second ed. Oxford Univ. Press, Oxford.

Slaymaker, O., 2011. Geomorphology and Global Environmental Change. Cambridge Univ. Press, Cambridge.

Stevenson, I., 1980. The diffusion of disaster: the phylloxera outbreak in the département of the Hérault, 1862-1880. J. Hist. Geogr. 6, 47-63. http://dx.doi.org/10.1016/03057488(80)90043-2.

Stoffel, M., Tiranti, D., Huggel, C., 2014. Climate change impacts on mass movements case studies from the European Alps. Sci. Total Environ. 493, 1255-1266. http://dx. doi.org/10.1016/j.scitotenv.2014.02.102.

Stokes, A., 2006. Selecting tree species for rockfall protection forests. For. Snow Landsc. Res. 80, 77-86.

Trappmann, D., Stoffel, M., Corona, C., 2014. Achieving a more realistic assessment of rockfall hazards by coupling three-dimensional, process based models and fieldbased tree-ring data. Earth Surf. Process. Landf. 39, 1866-1875.

Varnes, D.J., 1978. Slope movement types and processes. In: Schuster, R.L., Krizek, R.J. (Eds.), In Special Report 176. -Landslides: Analysis and control, Transp. Res. Board. National Research Council, Washington, D.C, pp. 11-33.

Vaudaine, A., 1930. Carte de la production viticole des Alpes françaises en 1927-1928. Rev. Géogr. Alp. 18, 215-217. http://dx.doi.org/10.3406/rga.1930.4528.

Veyret-Verner, G., 1937. L'agriculture du Grésivaudan. Rev. Géogr. Alp. 25, 273-346. http://dx.doi.org/10.3406/rga.1937.4076.

Volkwein, A., Schellenberg, K., Labiouse, V., Agliardi, F., Berger, F., Bourrier, F., Dorren, L.K.A., Gerber, W., Jaboyedoff, M., 2011. Rockfall characterisation and structural protection - a review. Nat. Hazards Earth Syst. Sci. 11, 2617-2651. http://dx.doi.org/10. 5194/nhess-11-2617-2011.

Warner, T.A., Campagna, D.J., 2009. Remote Sensing with IDRISI Taiga: A Beginner's Guide. GeoCarto, Hong Kong. 